\title{
Mineralization of vegetable oils used for thermal weed control in arable soils
}

\author{
Peter Gräßler $^{1} \cdot$ Nele Meyer $^{1,2}$ (D) - Jürgen Peukert ${ }^{3} \cdot$ Gerhard Welp $^{1} \cdot$ Lutz Damerow $^{3} \cdot$ Peter Schulze Lammers $^{3}$. \\ Wulf Amelung ${ }^{1}$
}

Received: 17 December 2018 / Revised: 23 March 2019 / Accepted: 25 March 2019 /Published online: 10 May 2019

(C) The Author(s) 2019

\begin{abstract}
Hot vegetable oil can be used for weed control as an alternative to the use of herbicides. We analysed the temporal development of vegetable oil mineralization in soil and tested the role of nutrient supply on oil mineralization. Further, we investigated the effect of oil application on mineralization of native soil organic carbon (SOC), i.e. the priming effect. In a laboratory experiment, three oil dosages $(0.1,1.0$ and $3.0 \mathrm{ml}$ per $35 \mathrm{~g}$ soil) were applied to three arable soils and soil respiration was measured hourly. Both a $\mathrm{C} 3$-sunflower oil and a $\mathrm{C} 4$-corn oil were used in order to differentiate oil-derived $\mathrm{CO}_{2}$ from $\mathrm{SOC}$-derived $\mathrm{CO}_{2}$. The results revealed that after 42 days of incubation, 9.6 to $39.7 \%$ of the applied oil was mineralized which, however, also primed the mineralization of SOC by a factor of 2.2 to 4.2 . The higher the applied oil amount, the lower was the percentage of oil-C mineralization, but the higher was the priming effect. The addition of fertilizer $\left(0.29 \mathrm{mg} \mathrm{N} \mathrm{g}^{-1}\right.$ soil and $0.048 \mathrm{mg} \mathrm{P} \mathrm{g}^{-1}$ soil $)$ increased oil-C mineralization to 39.9 to $50.9 \%$. We conclude that oil can temporarily accumulate in soil, especially in case of low nutrient supply. As the addition of oil stimulates SOC mineralization, a decrease of native SOC stocks may occur, which needs further quantification in long-term field experiments.
\end{abstract}

Keywords Microbial nitrogen mining $\cdot$ Nutrient limitation $\cdot$ Priming effect $\cdot$ Soil respiration

\section{Introduction}

Rising criticism on chemical weed control increases the need to develop ecological alternatives (Abbas et al. 2017; Ascard et al. 2007). In this regard, thermal weed control on the basis of hot vegetable oil could be an effective alternative for

Electronic supplementary material The online version of this article (https://doi.org/10.1007/s00374-019-01359-6) contains supplementary material, which is available to authorized users.

Nele Meyer

nele.meyer@helsinki.fi

1 Institute of Crop Science and Resource Conservation, Soil Science and Soil Ecology, University of Bonn, Nussallee 13, 53115 Bonn, Germany

2 Present address: Department of Forest Sciences, University of Helsinki, Latokartanonkaari 7, 00790 Helsinki, Finland

3 Institute of Agricultural Engineering, Systems Engineering in Plant Production, University of Bonn, Nussallee 5, 53115 Bonn, Germany synthetical herbicides on arable land, especially for intra-row weed management close to crops (Peukert 2018). Small amounts of 0.1 to $1.0 \mathrm{ml}$ of vegetable oil per weed are heated and applied selectively on single weeds (Peukert 2018). In this case, oil acts as a carrier of thermal energy and destroys plant cells by protein denaturation (Peukert et al. 2017; Zhang et al. 2012). Thereby, oil reaches the soil directly by dropping or flowing down or indirectly by decomposition of the killed weed. After developing this practice in laboratory and greenhouse successfully, the next step will be experiments in field (Peukert 2018). Generally, vegetable oil is not classified for physical or health hazards according to the Globally Harmonized System of Classification and Labelling of Chemicals (e.g. http://www.btps.ca/documents/general/ Vegetable_Oil.pdf 2011) and is already used as a carrier of other pesticides (Malkomes 2004). Yet, little is known about the mineralization rate of pure oil in soils and its determining factors. As an accumulation of oil in soils may have negative consequences for plant germination (Tamada et al. 2012) and physical soil properties like water repellence, infiltration, and aeration (Klamerus-Iwan et al. 2015; Sonnleitner et al. 2003), 
knowledge about the mineralization rate is necessary for recommendations of acceptable application rates.

It is generally assumed that vegetable oil, like rapeseed oil, is easily degradable and enzymes for its mineralization are ubiquitously existing (Cornish et al. 1993; Malkomes 2005; Zhang et al. 1998). Under aerobic conditions, vegetable oil in soils is completely mineralized to $\mathrm{CO}_{2}, \mathrm{H}_{2} \mathrm{O}$ and inorganic ingredients (Cornish et al. 1993). Several authors assessed the mineralization rate of vegetable oil in soil and the consequences of oily substrates on soil microorganisms (Malkomes 2004, 2005; Sonnleitner et al. 2003). Yet, the applied dosages were often different to those applied during thermal weed control (e.g. $5 \mathrm{ml}$ and $10 \mathrm{ml}$ per $100 \mathrm{~g}$ of soil were used in Sonnleitner et al. (2003), which is considerably higher than the recommended application of $0.1 \mathrm{ml}$ per weed), oils were mixed with other substances (Malkomes 2004, 2005), or olive oil mill wastewater was considered (Peikert et al. 2017). Thus, it is necessary to test the mineralization rate of purely and punctually applied oil as it is used for thermal weed control.

Vegetable oil is rich in C but comparatively poor in nutrients like N and P (Sonnleitner et al. 2003). Hence, an accumulation of vegetable oil in soils may induce a long-term microbial N incorporation (Malkomes 2004, 2005). Previous studies indicated that the mineralization rate of C-rich substrates depends on the availability of nutrients in soil (Meyer et al. 2018; Nordgren 1992). In this regard, it appears reasonable to suggest that nutrient supply also regulates the mineralization rate of oil in soils and that a deficiency of nutrients may retard or even limit the mineralization of oil.

On the other hand, it has been shown that the input of labile $\mathrm{C}$ (i.e. here vegetable oil) not only increases the demand of microorganisms for $\mathrm{N}$ but also provides energy for the breakdown of soil organic matter (SOM), which contains the required N ('microbial N mining theory', Craine et al. 2007). Such a stimulation of native SOC mineralization caused by labile $\mathrm{C}$ supply is commonly referred to as a positive priming effect (Kuzyakov et al. 2000). As several studies reported that positive priming is more pronounced under conditions of $\mathrm{N}$ deficiency (Blagodatskaya et al. 2007; Fontaine et al. 2011), the priming effect has increasingly been interpreted as a response of microbes to unsatisfied nutrient demand (Murphy et al. 2015). Hence, it seems reasonable to assume that the addition of oil stimulates the turnover of native SOC depending on the soil nutrient status. As previous studies focussed on the effect of oil addition on total $\mathrm{CO}_{2}$ release without distinguishing oil-derived from SOC-derived $\mathrm{CO}_{2}$ (e.g. Malkomes 2006; Sonnleitner et al. 2003), an effect of oil addition on native SOC mineralization has, to our knowledge, not been investigated yet.

This study aims at investigating the temporal dynamics of vegetable oil mineralization in soils and the response of native
SOC turnover to oil additions. As oil provides only low nutrient amounts for soil microorganisms, we assume that the mineralization rates of oil depend on nutrient supply and that fertilization increases the oil mineralization rate. Further, we assume that oil addition necessitates microbial nutrient mining, thereby increasing the priming effect, i.e. the mineralization of native SOC. To unravel these hypotheses, we added different dosages of naturally ${ }^{13} \mathrm{C}$-labeled vegetable oil with and without additional nutrient supply to three different soil samples, incubated them for 42 days at $22{ }^{\circ} \mathrm{C}$, and continuously measured $\mathrm{CO}_{2}$ release.

\section{Material and methods}

\section{Soil sampling}

Three soil samples with different SOC and nutrient contents were taken from arable fields in North Rhine-Westphalia, Germany (Table 1). Only C3 plants had been cultivated on these fields for at least the last decades, resulting in low $\delta^{13} \mathrm{C}$ values (Table 1). The altitude of the study sites ranged between 33 and $190 \mathrm{~m}$ above sea level. Samples were taken in spring. The fields were cultivated with winter wheat, sugar beet and one was prepared for sowing sugar beet. Basic soil properties are summarized in Table 1. At each sampling site, one sample was taken from 0 to $30 \mathrm{~cm}$ depth (Ap horizon) using a spade. The field-moist soil was stored at $7{ }^{\circ} \mathrm{C}$ for 1 week and sieved to $2 \mathrm{~mm}$, i.e. all results refer to the fine soil $<2 \mathrm{~mm}$. Sieved soils were divided into three parts: one was dried at $40^{\circ} \mathrm{C}$ for chemical analysis, one was stored frozen ($18{ }^{\circ} \mathrm{C}$ ) until the start of the incubation experiment, and one was stored field moist at $7{ }^{\circ} \mathrm{C}$ for determination of water holding capacity.

Table 1 Properties of the soil samples (arable soils, Ap horizon)

\begin{tabular}{|c|c|c|c|}
\hline & Soil 1 & Soil 2 & Soil 3 \\
\hline Sand $(\%)$ & 15.0 & 72.3 & 11.9 \\
\hline Silt (\%) & 63.4 & 20.3 & 62.7 \\
\hline Clay $(\%)$ & 20.7 & 6.0 & 22.6 \\
\hline N-total ( $\mathrm{g} \mathrm{kg}^{-1}$ soil) & 2.05 & 1.45 & 1.53 \\
\hline CAL-P (mg kg ${ }^{-1}$ soil $)^{\mathrm{a}}$ & 140 & 266 & 64.3 \\
\hline CAL-K (mg kg ${ }^{-1}$ soil $)^{\mathrm{a}}$ & 314 & 313 & 318 \\
\hline SOC ( g kg $^{-1}$ soil $)$ & 21.6 & 16.8 & 13.8 \\
\hline $\mathrm{C} / \mathrm{N}$ ratio & 10.5 & 11.6 & 9.0 \\
\hline $\mathrm{pH}$ in $\mathrm{CaCl}_{2}$ & 6.2 & 5.8 & 6.6 \\
\hline$\delta^{13} \mathrm{C}(\%)$ & -27.1 & -26.8 & -27.2 \\
\hline
\end{tabular}




\section{Soil physical and chemical analysis}

Texture was determined by a combination of wet sieving (sand fraction) and sedimentation (silt and clay fraction) after Köhn (ISO 11277 2002). The total C and N contents of milled soils were determined by elemental analysis (Vario MICRO Cube, Elementar, Hanau, Germany; ISO 10694 1995). All samples were free of carbonates, so total $\mathrm{C}$ corresponded to SOC. Plant available $\mathrm{P}$ and $\mathrm{K}$ were extracted by using the calcium-acetate-lactate method (Schüller 1969; Zbíral 2000). The concentration of $P$ was measured photometrically with the molybdenum blue method (Murphy and Riley 1962) and that of $\mathrm{K}$ by atomic absorption spectroscopy (AAS). The $\mathrm{pH}$ value was measured in a $0.01 \mathrm{M} \mathrm{CaCl}_{2}$ solution (soil:solution ratio of 1:2.5). Water holding capacity was determined on field moist soil by placing soil into funnels and submerging in water for $30 \mathrm{~min}$. Afterwards, soil was allowed to drain for $24 \mathrm{~h}$, weighed and dried at $105^{\circ} \mathrm{C}$.

\section{Incubation experiment}

The sieved and frozen soil samples were defrosted for 2 days at $7{ }^{\circ} \mathrm{C}$. Each soil sample was rewetted or dried to $45 \%$ of its water holding capacity, which warrants a sufficient and standardized water availability (ISO/DIS 17155 2001). Each sample was homogenized using a mixer and divided into 30 to 36 plastic vessels, each corresponding to $35 \mathrm{~g}$ of dry soil. The samples were then pre-incubated at $22^{\circ} \mathrm{C}$ for $96 \mathrm{~h}$ to level out effects of mixing and water addition and to stabilize the respiration rate (Blagodatsky et al. 2000).

After pre-incubation, oil was added to the soil samples. To differentiate between $\mathrm{CO}_{2}$ that evolved from the applied oil and $\mathrm{CO}_{2}$ that derived from native $\mathrm{SOC}$, we used commercially produced oil from corn (' $\mathrm{C} 4$ oil') that differs from the native SOC in terms of its $\delta^{13} \mathrm{C}$ value (Bol et al. 2003; Kuzyakov and Bol 2006 for distinguishing slurry-derived $\mathrm{CO}_{2}$ from SOCderived $\mathrm{CO}_{2}$ or Nottingham et al. 2009; Meyer et al. 2017 for distinguishing sugar-derived $\mathrm{CO}_{2}$ from SOC-derived $\mathrm{CO}_{2}$ ). The $\delta^{13} \mathrm{C}$ value of the $\mathrm{C} 4$ oil was $-16.65 \%$. The differentiation of oil- and SOC-derived $\mathrm{CO}_{2}$ based on the $\delta^{13} \mathrm{C}$ value of released $\mathrm{CO}_{2}$ would be straightforward if no isotopic fractionation occurred during mineralization. However, several studies indicated that isotopic fractionation does occur (e.g. Fernandez et al. 2003), which may lead to immense errors in the quantification of $\mathrm{CO}_{2}$ sources. To account for isotopic fractionation of the $\mathrm{C} 4$ oil, we followed suggestions of Bol et al. (2003) and conducted the same experiment also with a $\mathrm{C} 3$ control. For this, oil with a similar $\delta^{13} \mathrm{C}$ value as native $\mathrm{SOC}$ is required as $\mathrm{C} 3$ control. Therefore, we used a $\mathrm{C} 3$ sunflower oil, which was mixed with the $\mathrm{C} 4$ corn oil at a ratio of $5: 1$ to obtain the required isotope ratio $(-27.19 \%$, ' $\mathrm{C} 3$ oil'). Pre-tests revealed no difference in soil respiration rates between the two oils. The $\delta^{13} \mathrm{C}$ value of oil samples was determined by isotope ratio mass spectroscopy (IRMS, Thermo Delta V Advantage, Thermo Electron, Bremen, Germany) after weighing $0.5 \mathrm{mg}$ of oil and 0.1 to $0.2 \mathrm{mg}$ of C-free 'Chromosorb' into tin cups; the latter was used to absorb the oil. Total $\mathrm{N}$ contents were determined by elemental analysis as already reported. Total P was determined by ICPOES (Horiba Jobin Yvon, Ultima 2) after digestion with concentrated nitric acid. Both oils had a C content of $79.6 \%$, a N content of $<0.007 \%$ and a P content of $2.9 \mathrm{mg} \mathrm{P} \mathrm{kg}^{-1}$ oil (C3 oil) and $3.25 \mathrm{mg} \mathrm{P} \mathrm{kg}^{-1}$ (C4 oil), respectively.

The oils were applied with a nozzle according to Peukert et al. (2017). The nozzle height above soil was $15 \mathrm{~cm}$. During application, the oil was mixed constantly with the soil using a vortex shaker. Three different dosages were applied (see Table 2): five drops per vessel, i.e. per $35 \mathrm{~g}$ soil ('low dosage', $0.1 \mathrm{ml}$ oil vessel ${ }^{-1} ; \approx 3 \times 10^{-3} \mathrm{ml} \mathrm{g}^{-1}$ soil), 50 drops per vessel ('medium dosage', $1.0 \mathrm{ml}$ oil vessel $^{-1} ; \approx 0.03 \mathrm{ml} \mathrm{g}^{-1}$ soil) and 150 drops per vessel ('high dosage', $3.0 \mathrm{ml}$ oil vessel ${ }^{-1} ; \approx$ $0.09 \mathrm{ml} \mathrm{g}^{-1}$ soil). The dosages 'low' and 'medium' were chosen in order to simulate realistic dosages: Peukert (2018) proposed the punctual application of $0.1 \mathrm{ml}$ to maximal $1.0 \mathrm{ml}$ oil to a single weed plant. Thus, assuming that one weed plant grows on the vessel area of $28.3 \mathrm{~cm}^{2}$ the dosages low and medium represent the lower and upper range of recommended dosages. The high dosage of $3.0 \mathrm{ml}$ oil was conducted to simulate effects like inadvertent release of oil or a very high weed cover. The applied oil had a temperature of $22^{\circ} \mathrm{C}$. Note that we also tested the effect of higher oil temperatures during application $\left(100^{\circ} \mathrm{C}\right)$. As results were not significantly different between 22 and $100^{\circ} \mathrm{C}$ (Table S1), we concentrate here on reporting only results of the $22{ }^{\circ} \mathrm{C}$ treatments.

To test effects of nutrient limitation on oil mineralization, the oil dosages low and medium were conducted in combination with an additional nutrient supply. The variant with 'high' oil amount was excluded because the stimulation of microorganisms was expected to be too high to allow for a continuous measurement of $\mathrm{CO}_{2}$ release. The applied powdery nutrient mixture contained $47.88 \mathrm{mg}\left(\mathrm{NH}_{4}\right)_{2} \mathrm{SO}_{4}\left(0.29 \mathrm{mg} \mathrm{N} \mathrm{g}^{-1}\right.$ soil $)$, $7.42 \mathrm{mg} \mathrm{KH}_{2} \mathrm{PO}_{4}\left(0.048 \mathrm{mg} \mathrm{P} \mathrm{g}^{-1}\right.$ soil), and $154.7 \mathrm{mg}$ talcum powder per vessel. These amounts of nutrients were proposed by ISO/DIS 17155 (2001), and talcum powder was used as an inert carrier (Anderson and Domsch 1978). The powder was mixed to the soil immediately before addition of oil using a vortex shaker.

As it is known that microbial nutrient demand forces the acquisition of nutrients from SOM, we tested whether this 'nutrient mining' is as effective in providing nutrients required for oil mineralization as the addition of mineral nutrients. To test this, we repeated the abovementioned nutrient addition to selected vessels after finishing the incubation experiment at day 42 , i.e. to vessels that already received nutrients at the beginning of the experiment (second nutrient addition) and to vessels that did not receive nutrients at the beginning (first 
Table 2 Treatments of the incubation experiment including maximum hourly respiration rate $\left(\mathrm{CO}_{2 \max }\right)$ and time until the first respiration peak is reached $\left(t_{\mathrm{CO} 2 \max }\right)(n=2$ or 3$)$

\begin{tabular}{lllll}
\hline Treatment & Amount of added oil per vessel & Nutrient addition & $\mathrm{CO}_{2 \max }\left(\mathrm{mg} \mathrm{CO}_{2} \mathrm{~h}^{-1}\right) \mathrm{Mean} \pm \mathrm{SD}$ & $t_{\mathrm{CO} 2 \mathrm{max}}(\mathrm{h}) \mathrm{Mean} \pm \mathrm{SD}$ \\
\hline 1 & Low $(0.1 \mathrm{ml})$ & No & $0.4 \pm 0.2$ & $77 \pm 45$ \\
2 & Medium $(1.0 \mathrm{ml})$ & No & $1.5 \pm 0.6$ & $37 \pm 5$ \\
3 & High $(3.0 \mathrm{ml})$ & No & $1.5 \pm 0.6$ & $35 \pm 5$ \\
4 & Yow $(0.1 \mathrm{ml})$ & Yes & $5.9 \pm 1.4$ & $64 \pm 11$ \\
5 & Medium (1.0 ml) & No & & $60 \pm 1$ \\
6 & Control (none) & Yes & & \\
7 & Control (none) & & \\
\hline
\end{tabular}

nutrient addition). If nutrient mining by microbes releases the demanded amount of nutrients, $\mathrm{CO}_{2}$ release would not increase upon the late nutrient addition to vessels that had not received nutrients at the beginning.

We also conducted a control treatment, which received neither oil nor nutrients, and a treatment, which received nutrients but no oil. Thus, every soil sample was split into seven treatments with two (for two soils and the dosage low) or three analytic replications each (Table 2).

Soil microbial respiration was measured using an automated respirometer that allows incubating 95 samples in parallel (Respicond VIII, Nordgren Innovations AB, Sweden). The plastic incubation vessels are arranged in a water bath, which ensures a constant soil temperature of $22{ }^{\circ} \mathrm{C}$. The system provides a continuous measurement of $\mathrm{CO}_{2}$ evolution by trapping $\mathrm{CO}_{2}$ in potassium hydroxide $(\mathrm{KOH})$ (Nordgren 1988). Soil respiration was measured hourly for $1008 \mathrm{~h}$, i.e. for 42 days. As the $\mathrm{KOH}$ solution has a finite capacity to capture $\mathrm{CO}_{2}$, it was replaced several times during the incubation period in case that about half to three-quarter of the capacity was reached. During replacement, aeration of the samples and equilibration with ambient $\mathrm{O}_{2}$ was allowed.

From the respiration curve, the maximum hourly respiration rate (respiratory peak, $\mathrm{CO}_{2 \max }$ ) was derived as an indicator of nutrient availability (Meyer et al. 2017; Nordgren 1992). In case that two respiratory peaks developed during incubation (cf. Fig. 1), $\mathrm{CO}_{2 \max }$ describes the height of the first peak, which usually occurred within the first $130 \mathrm{~h}$ after oil addition. Further, we calculated the time needed until this peak was reached $\left(t_{\mathrm{CO} 2 \max }\right)$, which indicates the viability of microorganisms (ISO/DIS 17155 2001). Total cumulative amounts of released $\mathrm{CO}_{2}$ during the entire incubation period $\left(\mathrm{CO}_{2 \mathrm{cum}}\right)$ were calculated by summing up all hourly values of $\mathrm{CO}_{2}$ release.

\section{Quantification of oil- and SOC-derived $\mathrm{CO}_{2}$}

To obtain the $\delta^{13} \mathrm{C}$ value of released $\mathrm{CO}_{2}$, which allows distinguishing SOC-derived from oil-derived $\mathrm{CO}_{2}$, the $\mathrm{CO}_{2}$ captured within $\mathrm{KOH}$ had to be precipitated. The $\mathrm{KOH}$ solution was replaced several times during the incubation period (see above), and the replaced solution of every vessel was collected in airtight bottles. After completion of the incubation experiment, the bottles (each of them containing the entire $\mathrm{KOH}$ collected from each vessel) were shaken and excess $\mathrm{BaCl}_{2}$ solution ( $3 \mathrm{ml}$ of $1 \mathrm{M} \mathrm{BaCl}_{2}$ ) was added to a $20 \mathrm{ml}$ aliquot of the replaced $\mathrm{KOH}$. The addition of $\mathrm{BaCl}_{2}$ induced an immediate precipitation of $\mathrm{BaCO}_{3}$. The solution was vacuum-filtered with glass fibre filters and rinsed with distilled water. The remaining $\mathrm{BaCO}_{3}$ was dried at $40{ }^{\circ} \mathrm{C}$ and homogenized by grinding. About $1.6 \mathrm{mg}$ of the precipitated $\mathrm{BaCO}_{3}$ was weighed into tin cups, corresponding to $100 \mu \mathrm{g} \mathrm{C}$ per tin cup. Measurements of $\delta^{13} \mathrm{C}$ were conducted with isotope-ratio mass spectrometry (IRMS, Delta V Advantage Thermo Electron, Bremen, Germany).

The difference in the $\delta^{13} \mathrm{C}$ value between $\mathrm{CO}_{2}$ respired after additions of $\mathrm{C} 3$ oil and $\mathrm{C} 4$ oil in each sample, and treatment was used to quantify the proportion of oil- and SOC-derived $\mathrm{CO}_{2}$ to total $\mathrm{CO}_{2}$ release (Bol et al. 2003; Eq. 1). $\delta \mathrm{CO}_{2 \backslash \mathrm{C} 4}$ and $\delta \mathrm{CO}_{2 \backslash \mathrm{C} 3}$ are the $\delta^{13} \mathrm{C}$ values of the $\mathrm{CO}_{2}$ of the respective variant, whereas the subtraction of the $\mathrm{C} 3$ variant corrects the microbial isotope fractionation and adjusts this effect. The variables $\delta \mathrm{C}_{4}$ and $\delta \mathrm{C}_{3}$ are the $\delta^{13} \mathrm{C}$ values of the applied $\mathrm{C} 4$ oil $\left(\delta \mathrm{C}_{4}\right)$ and $\mathrm{C} 3$ oil $\left(\delta \mathrm{C}_{3}\right)$.

Proportion of oil derived $\mathrm{CO}_{2}$ to total $\mathrm{CO}_{2}(\%)$

$$
=\frac{\delta C O_{2 \backslash C 4}-\delta C O_{2 \backslash C 3}}{\delta C_{4}-\delta C_{3}} \times 100
$$

Absolute amounts of $\mathrm{CO}_{2}$ derived from oil during the whole incubation time were calculated by Eq. 2, i.e. the proportion of oil-derived $\mathrm{CO}_{2}$ from Eq. 1 was multiplied with the respective cumulative amount of $\mathrm{CO}_{2}\left(\mathrm{CO}_{2 \text { cum }}\right)$.

Absolute amount of oil derived $\mathrm{CO}_{2}(\mathrm{mg} \mathrm{CO}$ vessel-1)

$$
=\frac{\delta C O_{2} \backslash C 4-\delta C O_{2} \backslash C 3}{\delta C_{4}-\delta C_{3}} \times C O_{2 c u m}
$$


The amount of $\mathrm{C}$ applied by the oils depended on the variant. The estimated oil density at $22{ }^{\circ} \mathrm{C}$ of $0.91 \mathrm{~g} \mathrm{ml}^{-1}$ (following Esteban et al. 2012) was multiplied by the oil amount (ml) of each treatment (oil amount) and the Cproportion of $79.6 \%$ of the oils in Eq. 3 .

Amount of added $\mathrm{C}$ via oil addition ( $\mathrm{mg} \mathrm{C}$ vessel $^{-1}$ )

$$
=\text { oil amount } \times 0.91 \frac{\mathrm{g}}{\mathrm{ml}} \times 0.796 \times 1000
$$

Subsequently, the mineralization of oil was expressed as the loss of oil-C after 42 days of incubation, which was calculated according to Eq. 4, based on a proportion of $27.3 \% \mathrm{C}$ of $\mathrm{CO}_{2}$. Hence, the $\mathrm{CO}_{2}$ amount derived from oil (Eq. 2) was multiplied by 0.273 and divided by the respective amount of added $\mathrm{C}$ (Eq. 3). Thus, we got the relative oil mineralization within the incubation period.

Mineralization of oil-C after 42 days (\%)

$$
\begin{aligned}
= & \frac{\text { absolute amount of oil derived } \mathrm{CO}_{2} \times 0.273}{\text { amount of added } \mathrm{C}} \\
& \times 100
\end{aligned}
$$

The amount of SOC-derived $\mathrm{CO}_{2}$ was calculated by subtracting the amount of oil-derived $\mathrm{CO}_{2}$ (Eq. 2) from the total amount of $\mathrm{CO}_{2}\left(\mathrm{CO}_{2 \text { cum }}\right)$. The priming effect, i.e. the extra amount of $\mathrm{CO}_{2}$ that was derived from $\mathrm{SOC}$ compared to the control was calculated according to Eq. 5 , i.e. by dividing the amount of $\mathrm{CO}_{2}$ respired from native SOC after oil addition by the amount of $\mathrm{CO}_{2}$ respired in the control $\left(\mathrm{CO}_{2 \text { cum }} \mathrm{Control}\right)$, which received neither oil nor nutrients or no oil but nutrients (Bol et al. 2003).

Priming effect $=\frac{\mathrm{SOC} \text { derived } \mathrm{CO}_{2}}{\mathrm{CO}_{2 \text { cum }} \text { Control }}$

\section{Statistical analyses}

The average of the two to three replicates from each sample and treatment was used for statistical analyses. After each replacement of $\mathrm{KOH}$, the values of the first $2 \mathrm{~h}$ afterwards were deleted because $\mathrm{O}_{2}$ and $\mathrm{CO}_{2}$ from atmosphere came into the vessels. To investigate differences between the treatments, we conducted a three-way ANOVA with the factors oil dosage, fertilization, and sampling site, whereas the latter was considered as block effect. We also tested the interaction between oil dosage and fertilization. In case of significant effects $(p<0.05)$, Tukey HSD post-hoc test was carried out to compare differences between treatments. We checked for normal distribution of the data with Shapiro-Wilk test and for variance homogeneity with Levene's test. However, due to the small number of independent soil samples $(n=3)$, statistical test results should not be overinterpreted. Yet, they are useful to indicate tendencies. All statistical analyses were performed with R (version 3.2.3, R Core Team 2013).

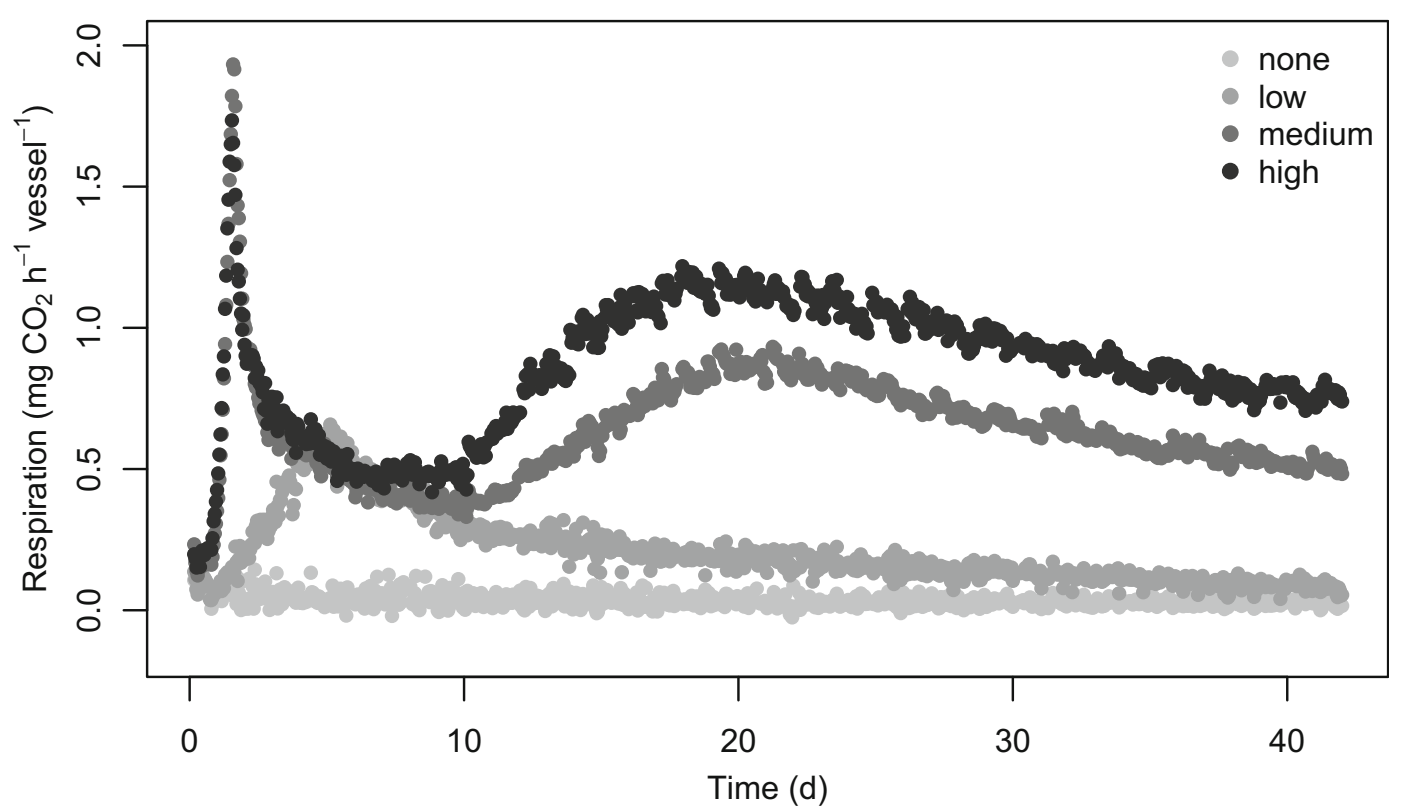

Fig. 1 Hourly $\mathrm{CO}_{2}$ release during the 42 days incubation period as affected by oil dosage (without nutrient additions). Results are shown exemplarily for soil 2 


\section{Results}

\section{Total $\mathrm{CO}_{2}$ release after oil addition}

The addition of oil induced an exponential increase of soil respiration in all samples (see Fig. 1). The maximum respiratory peak of this exponential increase $\left(\mathrm{CO}_{2 \max }\right)$ within the first $130 \mathrm{~h}$ after oil addition was significantly larger in the mediumdosage treatment $\left(1.5 \pm 0.6 \mathrm{mg} \mathrm{CO}_{2} \mathrm{~h}^{-1}\right)$ than in the lowdosage treatment $\left(0.4 \pm 0.2 \mathrm{mg} \mathrm{CO}_{2} \mathrm{~h}^{-1}\right.$; see Table S2 for detailed ANOVA output). In the high-dosage treatment, however, the maximum respiratory peak did not further increase (Table 2). Likewise, the time needed to reach the first peak $\left(t_{\mathrm{CO} 2 \mathrm{max}}\right)$ decreased when the amount of oil exceeded the minimum amount, without significant differences between medium-dosage and high-dosage treatments (Table 2). After reaching $\mathrm{CO}_{2 \max }$, the hourly respiration rate continuously decreased in the low-dosage treatment but developed a second respiratory peak in the medium-dosage and high-dosage treatments (Fig. 1).

Total $\mathrm{CO}_{2}$ release was significantly higher after oil addition compared to the control (Fig. 2a); treatments with low dosage released more than five times more $\mathrm{CO}_{2}$ than samples without oil. The higher the oil dosage, the more $\mathrm{CO}_{2}$ was released during the whole incubation time of 42 days (Fig. 1). Yet, the cumulative amount of $\mathrm{CO}_{2}$ release did not increase proportionally with increasing oil dosage (Fig. 2a).

Fertilization had no significant influence on total $\mathrm{CO}_{2}$ release $\left(\mathrm{CO}_{2 \text { cum }}\right)$ in the treatments without oil application (Fig. 2a). Adding nutrients together with the oil induced slight increases of the peak respiration rate $\left(\mathrm{CO}_{2 \max }\right)$ and total $\mathrm{CO}_{2}$ release $\left(\mathrm{CO}_{2 \text { cum }}\right)$ in the low-dosage treatment, which were, however, not significant. In contrast, the effect of nutrient additions on $\mathrm{CO}_{2 \text { cum }}$ and $\mathrm{CO}_{2 \max }$ was significant in the medium-dosage treatment: $\mathrm{CO}_{2 \text { cum }}$ was 1.9 times magnified compared to the variant without nutrients and $\mathrm{CO}_{2 \max }$ increased by a factor of 3.9 (see Fig. $2 \mathrm{a}$ and 3 ). A second nutrient addition at day 42 did not result in a considerable stimulation of $\mathrm{CO}_{2}$ release (Fig. 3). In contrast, samples that received nutrients for the first time at day 42 developed a pronounced respiratory peak (Fig. 3).

\section{Mineralization of oil}

As already observed for $\mathrm{CO}_{2 \text { cum }}$, oil-C mineralization did not increase proportionally with oil dosage: the triplication of oil dosage from the medium-dosage to the high-dosage treatments did not result in a 3 -fold increase of oil-C mineralization but only increased by a factor of 1.3 (Fig. 2b). As a result, percentage mineralization of oil-C after 42 days of incubation decreased with increasing oil dosage. This decrease was evident in all samples, although the difference was only significant between the low-dosage and the medium-dosage treatments and the low-dosage and high-dosage treatments (Fig. 2b).

Fertilization increased absolute amounts and the percentage oil-C mineralization (Fig. 2b) in both tested dosages, but the effect was only significant for the mediumdosage treatment: here, the mineralization of oil-C increased 1.9 times by fertilization (Fig. 2b). By pairwise comparing the mineralization of each soil sample with and without nutrients, oil-C mineralization was always higher after nutrient addition.

\section{Effect of oil addition on soil organic C mineralization}

The addition of oil increased the mineralization of SOC in all treatments compared to the control, i.e. we observed that positive priming effects $>1$ occurred (Fig. 2c). The priming effect increased with increasing amounts of oil addition, though this difference was statistically not significant (Fig. 2c).

The addition of nutrients resulted in a significantly higher priming effect in the medium-dosage treatment but had no significant effect on priming in the low-dosage treatment (Fig. 2c).

\section{Discussion}

\section{Mineralization of oil}

All tested soils showed an increased $\mathrm{CO}_{2}$ release after oil addition. The addition of $\mathrm{C}$ via oil resulted in an exponential increase of soil respiration. This immediate and exponential respiration response to oil addition is similar to what is usually observed after addition of highly labile substrates (e.g. glucose in Blagodatsky et al. 2000; Nordgren 1992). Hence, we assume that vegetable oils contain besides recalcitrant compounds also considerable amounts of easily mineralizable $\mathrm{C}$.

Various publications state that vegetable oils are a mixture of different substances, which are completely mineralizable by microorganisms (e.g. Zhang et al. 1998). Yet, in our experiments after 42 days of incubation at $22{ }^{\circ} \mathrm{C}$ and optimal conditions of soil moisture (ISO/DIS 17155 2001), oil-C was mineralized by $64 \%$ at maximum (soil 2, addition of $0.1 \mathrm{ml}$ oil, with nutrient addition; Fig. 2b). The amount of mineralized oil-C did not increase proportionally with increasing amounts of oil addition. Hence, the proportion of mineralized oil-C decreased with increasing amounts of added oil. This indicates that the overall mineralization of oil is limited at high dosages of application, which may lead to a temporary accumulation of oil in soils.

The limitation of oil mineralization at high dosages might be caused by a lack of available nutrients. There are two indications that nutrient supply regulates the mineralization rate of 

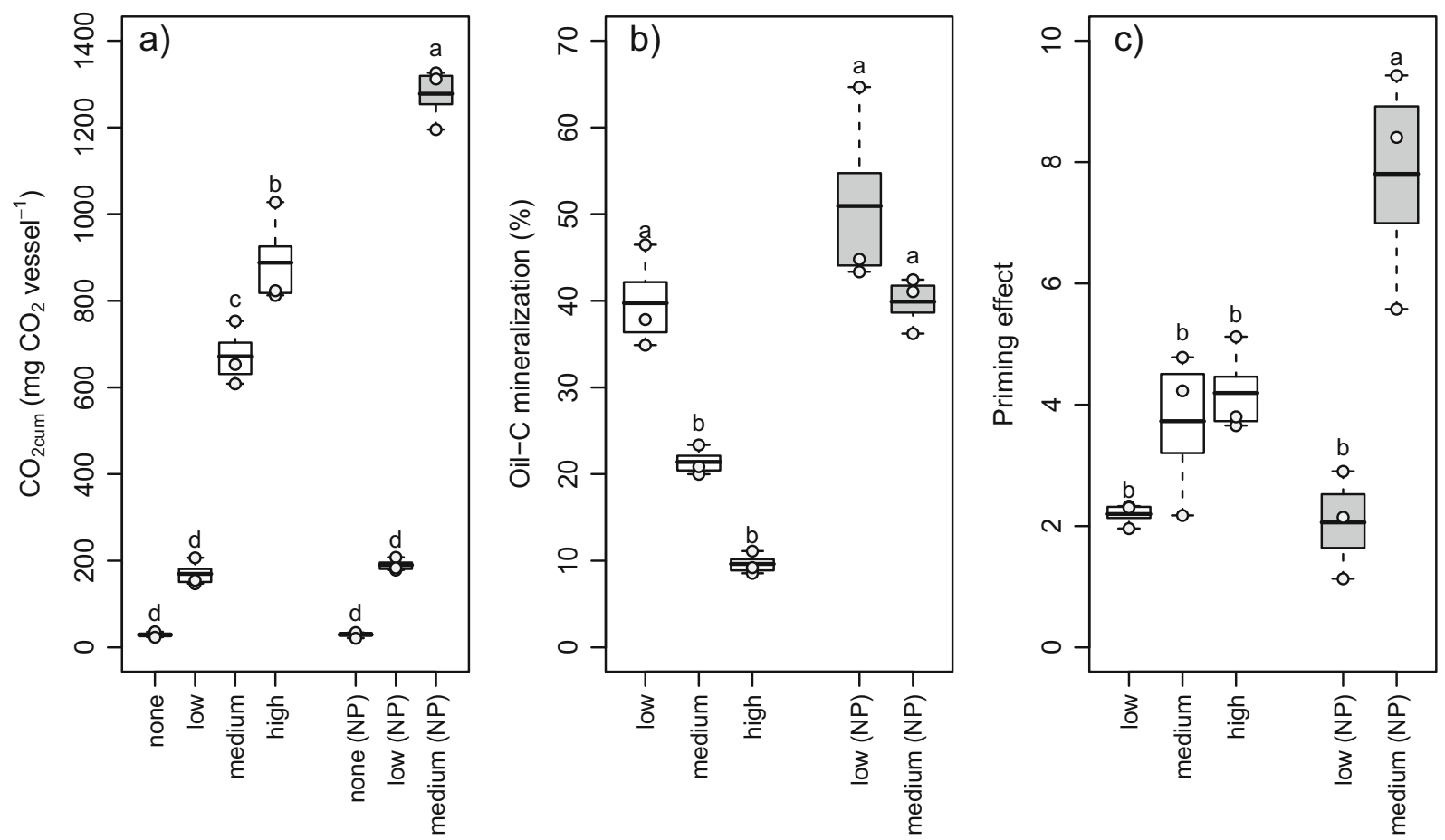

Fig. 2 Results of the incubation experiment. a Cumulative $\mathrm{CO}_{2}$ release, $\mathrm{CO}_{2 \text { cum. }}$ b Oil-C mineralization. $\mathbf{c}$ Priming effect depending on the applied oil dosage and nutrient supply. Treatments with nutrient addition are highlighted in grey. The light grey circles show the results of each individual sample

vegetable oil in soils. (1) The height of the respiratory peak $\left(\mathrm{CO}_{2 \max }\right)$ increased from the low-dosage to the mediumdosage treatments but did not increase any further in the high-dosage treatment. The height of a respiratory peak after the addition of labile $\mathrm{C}$ has often been interpreted as an indicator for the amount of immediately available nutrients because microbial growth continues until either the labile parts of the added substrates or the required nutrients are consumed (e.g. Nordgren 1992). Hence, it appears reasonable to speculate that nutrient supply was sufficient at low dosages but did not meet microbial demand at higher application dosages. (2) The addition of nutrients together with oil application increased $\mathrm{CO}_{2 \text { cum }}$ and the proportion of mineralized oil-C especially in the medium-dosage treatment (Fig. 2a, b). A stimulation of oil mineralization by nutrient addition was also observed by Malkomes (2004). Hence, sufficient nutrient supply increases oil mineralization rates.

If not enough nutrients are available, microorganisms may also be able to acquire the required nutrients from SOM, which is referred to as 'microbial nutrient mining' (Craine et al. 2007; Moorhead and Sinsabaugh 2006). The development of a second respiratory peak may point to this mechanism (Beck 1991; Meyer et al. 2017; Teklay et al. 2006), although other mechanisms like changes in the microbial community composition could also explain this phenomenon. To test whether such nutrient mining may release sufficient amounts of nutrients for oil mineralization, we applied nutrients after finishing the experiment at day 42 to some vessels that did not receive nutrients at the beginning. The results revealed that nutrient additions induced an increased $\mathrm{CO}_{2}$ release and a respiratory growth phase even after day 42 (Fig. 3), grey symbols. This indicates that oil mineralization was still nutrient limited in these samples and that nutrient mining, if it occurred, did not release enough nutrients to meet microbial demand. Hence, at higher oil application dosages, the required nutrient demand only seemed to be met in samples that received additional nutrients (Fig. 3, black symbols).

We are aware that oil can create impermeable layers in soil and may act as a diffusion barrier for oxygen (Klamerus-Iwan et al. 2015), thereby potentially also creating anaerobic conditions. We therefore cannot exclude that organic intermediates are produced in addition to $\mathrm{CO}_{2}$, which, however, could not be measured using the Respicond. This could lead to underestimation of oil and SOC mineralization. Yet, due to the comparatively small amount of oil addition and the regular ventilation, anoxic conditions are likely to occur only on small microsites but not in the entire incubation vessel. As organic intermediates and $\mathrm{CH}_{4}$ are usually rapidly re-oxidized to $\mathrm{CO}_{2}$ when transported through soil (Mancinelli 1995), even an anaerobic degradation mechanisms might finally result in $\mathrm{CO}_{2}$ release. In addition, rates of anaerobic oil degradation and associated $\mathrm{CH}_{4}$ evolution are low compared with mineralization to $\mathrm{CO}_{2}$ (Ward et al. 1980). 


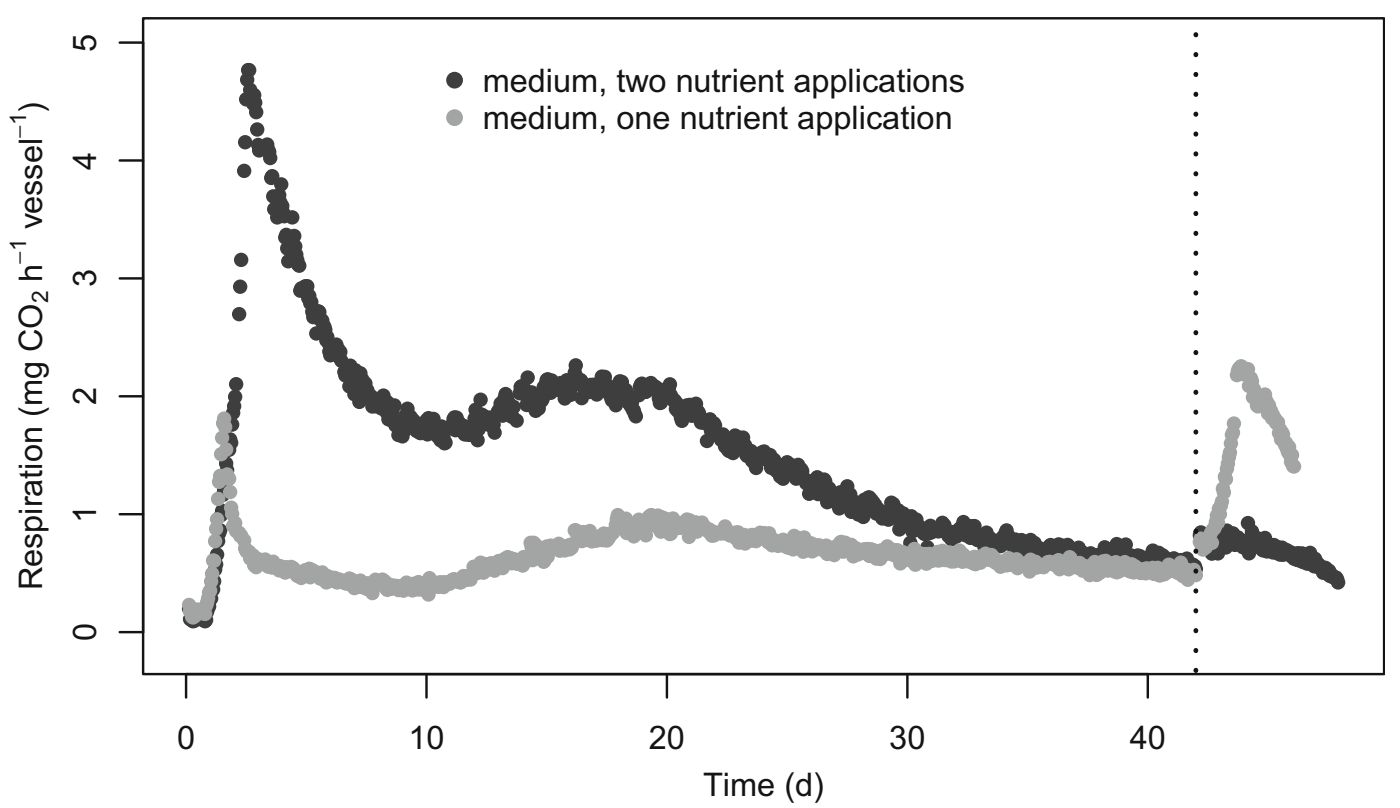

Fig. 3 Effect of nutrient additions on hourly $\mathrm{CO}_{2}$ release. Samples received either a nutrient mixture (black symbols) or no nutrients (grey symbols) together with the oil at the beginning of incubation (day 0). At day 42 , both samples received nutrients either for the second time (black symbols) or for the first time (grey symbols). The curve with black symbols was not exactly congruent after day 42 due to mixing effects. Results are shown exemplarily for the 'medium-dosage' treatment of soil 2

\section{Effect of oil addition on SOC mineralization}

The application of vegetable oil resulted in a stimulation of native SOC mineralization, i.e. we observed a priming effect $>1$ in all treatments. Kuzyakov et al. (2000) reported priming effects $>1$ after adding a wide range of labile $\mathrm{C}$ substrates. The addition of labile $\mathrm{C}$ may increase the activity of microorganisms, thereby also stimulating the turnover of less easily mineralizable native SOC (Alvarez and Alvarez 2000; Chen et al. 2014; Kuzyakov et al. 2000). As we observed that vegetable oil contains considerable proportions of easily mineralizable C (see above), it seems reasonable to assume that it also stimulates the turnover of SOC.

The driving force behind the priming effect continues to be the subject of controversial discussion. According to Craine et al. (2007), the presence of labile C sources increases the demand for nutrients but provides energy for the breakdown of SOM, which contains the required nutrients. As the breakdown of SOM involves mineralization of $\mathrm{C}$ contained within the SOM, the priming effect has correspondingly been interpreted as a response of microbes to nutrient deficiency (Murphy et al. 2015). The development of a second microbial growth phase in the presumably nutrient limited treatments medium dosage and high dosage may thus indicate such a microbial nutrient mining, i.e. a delayed release of previously unavailable nutrients (Meyer et al. 2017; Teklay et al. 2006).
Noteworthy and contrary to the assumption of a deficiency-regulated priming effect, however, the addition of nutrients did not decrease the priming effect. Instead, it even increased priming in the medium-dosage treatment. In line with Meyer et al. (2018), this observation indicates that the demand for nutrients is not the primary mechanism regulating the priming effect, i.e. a release of previously unavailable nutrients from SOM must not be coupled with an increased priming effect. More likely, the oil-induced stimulation of microbial activity seems to enhance the mineralization of native SOC, which is more pronounced at sufficient nutrient supply.

\section{Conclusions}

Our study reveals that high amounts of vegetable oil-C are only rapidly mineralized in soil in case of sufficient nutrient supply. At higher application dosages or in nutrient poor soils, nutrient demand may exceed nutrient supply and induce a temporary accumulation of oil in soils. Likewise, it may also be expected that the oilinduced immobilization of nutrients has negative consequences for plant growth. For the stimulation of oil-C mineralization, we therefore recommend fertilizing the soil. The risk of oil accumulation in soil and of priming-induced depletion of SOC stocks needs further investigation by long-term field experiments. 
Acknowledgments We thank J. Dyckmans, K. Unger, and D. Rupprecht for their support with ${ }^{13} \mathrm{C}$ measurements.

Funding information Open access funding provided by University of Helsinki including Helsinki University Central Hospital. The research was financially supported by the Ministry for Environment, Agriculture, Conservation, and Consumer Protection, NRW under the project title: Hot Vegetable Oils for Weeding.

Open Access This article is distributed under the terms of the Creative Commons Attribution 4.0 International License (http:// creativecommons.org/licenses/by/4.0/), which permits unrestricted use, distribution, and reproduction in any medium, provided you give appropriate credit to the original author(s) and the source, provide a link to the Creative Commons license, and indicate if changes were made.

\section{References}

ISO 10694 (1995) Soil quality - determination of organic and total carbon after dry combustion (elementary analysis). ISO-Secretariat, Geneva

ISO/DIS 17155 (2001) Soil quality - determination of abundance and activity of the soil microflora using respiration curves. ISOSecretariat, Geneva

Abbas T, Zahir ZA, Naveed M, Kremer RJ (2017) Limitations of existing weed control practices necessitate development of alternative techniques based on biological approaches. Adv Agron 147:239-280

Alvarez R, Alvarez CR (2000) Soil organic matter pools and their associations with carbon mineralization kinetics. Soil Sci Soc Am J 64: 184-189

Anderson JPE, Domsch KH (1978) A physiological method for the quantitative measurement of microbial biomass in soils. Soil Biol Biochem 10:215-221

Ascard J, Hatcher PE, Melander B, Upadhyaya MK (2007) Thermal weed control. In: Upadhyaya MK, Blackshaw RE (eds) Nonchemical weed management. CABI, Wallingford, pp 155-175

Beck T (1991) Einsatzmöglichkeiten der substratinduzierten Atmungsmessung bei bodenmikrobiologischen Untersuchungen. Mitt Dtsch Bodenkdl Ges 66:459-462

Blagodatskaya EV, Blagodatsky SA, Anderson TH, Kuzyakov Y (2007) Priming effects in Chernozem induced by glucose and $\mathrm{N}$ in relation to microbial growth strategies. Appl Soil Ecol 37:95-105

Blagodatsky SA, Heinemeyer O, Richter J (2000) Estimating the active and total soil microbial biomass by kinetic respiration analysis. Biol Fertil Soils 32:73-81

Bol R, Moering J, Kuzyakov Y, Amelung W (2003) Quantification of priming and $\mathrm{CO}_{2}$ respiration sources following slurry-C incorporation into two grassland soils with different $\mathrm{C}$ content. Rapid Commun Mass Spectrom 17:2585-2590

Chen R, Senbayram M, Blagodatsky S, Myachina O, Dittert K, Lin X, Blagodatskaya E, Kuzyakov Y (2014) Soil C and N availability determine the priming effect: microbial $\mathrm{N}$ mining and stoichiometric decomposition theories. Glob Change Biol 20:2356-2367

Cornish A, Battersby NS, Watkinson RJ (1993) Environmental fate of mineral, vegetable and transesterified vegetable oils. Pestic Sci 37: $173-178$

Craine JM, Morrow C, Fierer N (2007) Microbial nitrogen limitation increases decomposition. Ecology 88:2105-2113

Esteban B, Riba JR, Baquero G, Rius A, Puig R (2012) Temperature dependence of density and viscosity of vegetable oils. Biomass Bioenergy 42:164-171
Fernandez I, Mahieu N, Cadisch G (2003) Carbon isotopic fractionation during decomposition of plant materials of different quality. Glob Biogeochem Cycles 17:1075

Fontaine S, Henault C, Aamor A, Bdioui N, Bloor JMG, Maire V, Mary B, Revaillot S, Maron PA (2011) Fungi mediate long term sequestration of carbon and nitrogen in soil through their priming effect. Soil Biol Biochem 43:86-96

ISO 11277 (2002) Soil quality - determination of particle size distribution in mineral soil material - method by sieving and sedimentation. ISO-Secretariat, Geneva

Klamerus-Iwan A, Błońska E, Lasota J, Kalandyk A, Waligórski P (2015) Influence of oil contamination on physical and biological properties of forest soil after chainsaw use. Water Air Soil Pollut 226:389

Kuzyakov Y, Bol R (2006) Sources and mechanisms of priming effect induced in two grassland soils amended with slurry and sugar. Soil Biol Biochem 38:747-758

Kuzyakov Y, Friedel JK, Stahr K (2000) Review of mechanisms and quantification of priming effects. Soil Biol Biochem 32:1485-1498

Malkomes HP (2004) Einfluss höherer Dosierungen eines Pflanzenschutzmittels auf Rapsöl-Basis auf mikrobielle Aktivitäten im Boden. Z Pflanzenkrankh Pflanzenschutz 111:484-493

Malkomes HP (2005) Mikrobiologisch-ökotoxikologische Bodenuntersuchungen von zwei im Pflanzenschutz eingesetzten Öl-Präparaten. UWSF Z Umweltchem Ökotox 17:77-84

Malkomes HP (2006) Einfluss von herbizidem Citronella-Öl und Neem (Azadirachtin) auf mikrobielle Aktivitäten im Boden. Gesunde Pflanzen 58:205-212

Mancinelli RL (1995) The regulation of methane oxidation in soil. Annu Rev Microbiol 49:581-605

Meyer N, Welp G, Bornemann L, Amelung W (2017) Microbial nitrogen mining affects spatio-temporal patterns of substrate-induced respiration during seven years of bare fallow. Soil Biol Biochem 104:175-184

Meyer N, Welp G, Rodinov A, Borchard N, Martius C, Amelung W (2018) Nitrogen and phosphorus supply controls soil organic carbon mineralization in tropical topsoil and subsoil. Soil Biol Biochem 119:152-161

Moorhead DL, Sinsabaugh RL (2006) A theoretical model of litter decay and microbial interaction. Ecol Monogr 76:151-174

Murphy J, Riley JP (1962) A modified single solution method for the determination of phosphate in natural waters. Anal Chim Acta 27: $31-36$

Murphy CJ, Baggs EM, Morley N, Wall DP, Paterson E (2015) Rhizosphere priming can promote mobilisation of N-rich compounds from soil organic matter. Soil Biol Biochem 81:236-243

Nordgren A (1988) Apparatus for the continuous, long-term monitoring of soil respiration rate in large numbers of samples. Soil Biol Biochem 20:955-957

Nordgren A (1992) A method for determining microbially available $\mathrm{N}$ and $\mathrm{P}$ in an organic soil. Biol Fertil Soils 13:195-199

Nottingham AT, Griffiths H, Chamberlain PM, Stott AW, Tanner EVJ (2009) Soil priming by sugar and leaf-litter substrates: a link to microbial groups. Appl Soil Ecol 42:183-190

Peikert B, Schaumann GE, Bibus D, Fischer J, Braun U, Brunkhardt J (2017) Effects of olive oil mill wastewater on chemical, microbiological, and physical properties of soil incubated under four different climatic conditions. Biol Fertil Soils 53:89-101

Peukert J (2018) Unkrautbekämpfung mit heißen Pflanzenölen Methodenentwicklung und experimentelle Bestimmung technischphysikalischer und biologischer Einflussgrößen. Dissertation, University Bonn

Peukert J, Schulze Lammers P, Damerow L (2017) Entwicklung eines Applikationssystems zur selektiven, thermischen Unkrautbekämpfung in Reihenkulturen mit Pflanzenöl. Landtechnik 72:202-213

R Core Team (2013) R: a language and environment for statistical computing. R Foundation for Statistical Computing, Vienna http://www. R-project.org/ 
Schüller H (1969) Die CAL-Methode, eine neue Methode zur Bestimmung des pflanzenverfügbaren Phosphates in Böden. Z Pflanzenernähr Bodenkd 123:48-63

Sonnleitner R, Lorbeer E, Schinner F (2003) Effects of straw, vegetable oil and whey on physical and microbiological properties of a chernozem. Appl Soil Ecol 22:195-204

Tamada I, Montagnolli R, Lopes P, Bidoia E (2012) Toxicological evaluation of vegetable oils and biodiesel in soil during the biomineralization process. Braz J Microbiol 43:1576-1581

Teklay T, Nordgren A, Malmer A (2006) Soil respiration characteristics of tropical soils from agricultural and forestry land-uses at Wondo Genet (Ethiopia) in response to C, N and P amendments. Soil Biol Biochem 38:125-133

Ward DM, Atlas RM, Boehm PD, Calder JA (1980) Microbial biodegradation and chemical evolution of oil from the Amoco spill. Ambio 9: 277-283
Zbíral J (2000) Determination of phosphorus in calcareous soils by mehlich 3, mehlich 2, cal, and egner extractants. Commu Soil Sci Plant Anal 31:3037-3048

Zhang X, Peterson CL, Reece D, Möller G, Haws R (1998) Biodegradability of biodiesel in the aquatic environment. Trans ASAE 41:1423-1430

Zhang Y, Staab ES, Slaughter DC, Giles DK, Downey D (2012) Automated weed control in organic row crops using hyperspectral species identification and thermal micro-dosing. Crop Prot 41:96105

Publisher's note Springer Nature remains neutral with regard to jurisdictional claims in published maps and institutional affiliations. 